\title{
Short Intro
}

This issue of Education for Information represents a first for the journal, and one that we are very pleased to present. It is perhaps a misnomer to refer to an issue when in fact it is a triple issue. Its size is explained by its inclusion of a large number of papers from the 2011 Asia-Pacific Conference on Library and Information Education and Practice (A-LIEP): Issues, Challenges and Opportunities (22-24 June 2011, Pullman Putrajaya Lakeside, Putrajaya, Malasia). The fourth A-LIEP provided a platform for participants to discuss, share, and debate on issues and challenges facing education and practice in the field of Library and Information Science (LIS), with particular emphasis on the Asia-Pacific region. The authors are drawn from a wide array of countries in the region and collectively they offer an exciting perspective on developments in the education sector. The papers were reviewed before presentation at the Conference and we thank the organisers for arranging to make them available for publication in Education for Information. 